\title{
Silicon Differentially Influences Copper Toxicity Response in Silicon-accumulator and Non-accumulator Species
}

\author{
Jonathan M. Frantz ${ }^{1}$ \\ USDA-ARS, Greenhouse Production Research Group, 2801 W. Bancroft, MS 604, Toledo, OH 43606 \\ Sushant Khandekar and Scott Leisner \\ Department of Biological Sciences, The University of Toledo, $2801 \mathrm{~W}$. Bancroft, MS 601, Toledo, OH \\ 43606
}

\begin{abstract}
AdDitional INDEX wORDS. zinnia, snapdragon, plant nutrition, micronutrient, floriculture, $\mathrm{Cu}, \mathrm{Si}$
Abstract. The use of copper $(\mathrm{Cu})$ in agriculture is widespread as a pesticide, and it is present in high concentrations in certain types of manures. As the use of $\mathrm{Cu}$ continues and manure management is incorporated into sustainable systems, the likelihood of $\mathrm{Cu}$ toxicity increases. Supplemental silicon has been used to successfully counteract potential micronutrient toxicity. There is currently considerable debate regarding the value of including silicon (Si) as a nutrient in fertility programs and as such, it is not part of a typical management practice in floriculture crop production in the United States. We investigated the potential for Si to ameliorate the effects of Cu toxicity in both a Siaccumulating [zinnia (Zinnia elegans)] and a Si-non-accumulating [snapdragon (Antirrhinum majus)] species. Using visible stress indicators and dry weight analysis, it initially appeared that $\mathrm{Si}$ was a significant benefit to only zinnia under $\mathrm{Cu}$ toxicity. Enzymatic assays and elemental analysis of leaves, stems, and roots revealed that both species responded to supplemental $\mathrm{Si}$, showing evidence of reduced stress and nutrient concentrations more similar to healthy, control plants than plants exposed to $\mathrm{Cu}$ toxicity. Although there appear to be differences in the extent of Simediated amelioration of $\mathrm{Cu}$ toxicity between these two plants, both responded to supplemental Si. This adds to the growing body of evidence that all plants likely have Si-mediated responses to stress, and its inclusion into fertility programs should be more broadly considered than current practices.
\end{abstract}

Worldwide, some soils are high in $\mathrm{Cu}$ leading to the natural occurrence of $\mathrm{Cu}$ toxicity (Alonso et al., 2000; Cook et al., 1997). Most reported $\mathrm{Cu}$ toxicity is the result of anthropogenic sources including pesticide use (Hoang et al., 2009) and use of young compost or pig manure (Alonso et al., 2000; Brady and Weil, 2001). In protected agriculture, growers have used electrolytically generated $\mathrm{Cu}$ (Zheng et al., 2004) for disinfecting irrigation water; it is not clear if U.S. Department of Agriculture (USDA) statistics account for this source of $\mathrm{Cu}$, so the extent of electrolytically generated $\mathrm{Cu}$ use is not known. Recommended rates of $\mathrm{Cu}$ ionization are from 7.8 to $15.7 \mu \mathrm{M}$. Additional $\mathrm{Cu}$ use is primarily from copper hydroxide $\left[\mathrm{Cu}(\mathrm{OH})_{2}\right]$ and copper sulfate $\left(\mathrm{CuSO}_{4}\right)$ with an average total rate of $\mathrm{Cu}$ use of just under $1.9 \mathrm{~kg} \cdot \mathrm{ha}^{-1}$ in floriculture and nursery alone (USDA, 2007). Typical concentrations (label rates) for different $\mathrm{Cu}$ containing fungicides range from 1,050 to over $19,000 \mu \mathrm{M}$.

The exact threshold between $\mathrm{Cu}$ sufficiency to toxicity is largely unknown for most floriculture crop species. A few greenhouse crops grown hydroponically have been well characterized and the $\mathrm{Cu}$ concentration that leads to plant stress (root discoloration, stunting, leaf chlorosis) is remarkably low: cucumber (Cucumis sativus) was $\approx 20 \mu \mathrm{M}$ (Zheng et al., 2010), pepper (Capsicum annuum) was $3 \mu \mathrm{M}$ at the seedling stage and

Received for publication 6 July 2011. Accepted for publication 15 Aug. 2011. We thank Russell Friedrich, Alycia Pittenger, Stephen Ohene-Larbi, and Douglas Sturtz for laboratory assistance.

Mention of a trademark, proprietary product, or vendor does not constitute a guarantee or warranty of the product by the USDA and does not imply its approval to the exclusion of other products or vendors that also may be suitable. ${ }^{1}$ Corresponding author. E-mail: jonathan.frantz@ars.usda.gov. between 8 and $16 \mu \mathrm{M}$ at the fruiting stage (Zheng et al., 2005), chrysanthemum (Dendranthema $\times$ grandiflorum) was $5 \mu \mathrm{M}$, miniature rose (Rosa $\times$ hybrida) was between 2.4 and $4.7 \mu \mathrm{M}$, and geranium (Pelargonium $\times$ hortorum) was $8 \mu \mathrm{M}$ (Zheng et al., 2004). Because matured organic substrates can bind significant amounts of $\mathrm{Cu}$ making it unavailable (Brady and Weil, 2001), the threshold for $\mathrm{Cu}$ supply to cause toxicity in peat-based substrates is thought to be considerably higher. Zheng has observed detrimental growth effects for chrysanthemum, miniature rose, and geranium at $63 \mu \mathrm{M} \mathrm{Cu}$ in the nutrient solution (Y. Zheng, personal communication), whereas Lee et al. (1996) reported leaf chlorosis at $250 \mu \mathrm{M} \mathrm{Cu}$ in the nutrient solution. It should be noted that in the study by Lee et al. (1996), no treatment levels between 5 and $250 \mu \mathrm{M}$ were examined.

Given the relatively low threshold for $\mathrm{Cu}$ toxicity and the greenhouse industry's use of $\mathrm{Cu}$ in fungicides as well as the capture and recirculation of water used in the greenhouse industry (Uva et al., 2001) that may carry residual $\mathrm{Cu}$ from different sources, there is potential to encounter $\mathrm{Cu}$ toxicity. Because early $\mathrm{Cu}$ toxicity often manifests as iron (Fe) deficiency and additional chelated $\mathrm{Fe}$ above and beyond the supply already found in complete water-soluble fertilizers can eliminate those symptoms (Bucher and Schenk, 2000), undiagnosed $\mathrm{Cu}$ toxicity in floriculture production may be more common than currently believed.

Silicon is not considered to be an essential plant nutrient because most plant species can complete their life cycle without it (Marschner, 1995). Still, some plant species can accumulate $\mathrm{Si}$ at concentrations higher than many essential macronutrients ["accumulators" herein described as species that accumulate Si at concentrations greater than $1000 \mathrm{mg} \cdot \mathrm{kg}^{-1}$ (Epstein, 1999)], 
and even so-called non-accumulating species (also known as "Si excluders" and defined herein as a species that accumulates less than $1000 \mathrm{mg} \cdot \mathrm{kg}^{-1}$ ) can acquire $\mathrm{Si}$ in their leaf tissues greater than micronutrients and some macronutrients (Frantz et al., 2008, 2010; Mattson and Leatherwood, 2010). Beneficial effects provided by $\mathrm{Si}$ are well documented for many field crops and a few ornamentals (Bélanger et al., 1995; Datnoff and Rodrigues, 2005; Gillman et al., 2003; Korndörfer and Lepsch, 2001; Ma et al., 1989; McAvoy and Bible, 1996; Rodrigues et al., 2004). One of the debates about $\mathrm{Si}$ in plant biology has been in the classification of plant species as Si accumulators or non-accumulators with varying definitions further separating those main groups. The debate has been instrumental in shaping how we perceive and study the role of $\mathrm{Si}$ in plant biology with some statements made that describe so-called non-accumulators as plants that do not respond to supplemental Si (Ma et al., 2001; Mitani and Ma, 2005).

Silicon has been shown to alleviate metal toxicity in a variety of plant species. Toxicity of zinc in the metal-tolerant Cardaminopsis halleri, a member of the Brassicaceae, is ameliorated in part by binding with $\mathrm{Si}$ and precipitating in cytoplasm or by cotransportation of Si and zinc ( $\mathrm{Zn}$ ) into extracellular compartments (Neumann and zur Nieden, 2001). Toxicity of manganese $(\mathrm{Mn})$ in soybean (Glycine max) appears to be alleviated by $\mathrm{Si}$ in part by enhancing the distribution of $\mathrm{Mn}$ throughout the plant thereby preventing it from reaching toxic levels in a specific site (Horst and Marschner, 1978). Cowpea (Vigna unguiculata) has been extensively studied with regard to alleviating $\mathrm{Mn}$ toxicity with supplemental Si (Iwasaki et al., 2002a, 2002b, 2002c). In those studies, Si acts to detoxify Mn both through increased binding of $\mathrm{Mn}$ on cell wells and interaction between $\mathrm{Mn}$ and soluble Si in the apoplast. Toxicity of $\mathrm{Cu}$ in arabidopsis (Arabidopsis thaliana) was shown to be alleviated by $\mathrm{Si}$ through active metal transporter regulation $(\mathrm{Li}$ et al., 2008), but alleviating $\mathrm{Cu}$ toxicity with $\mathrm{Si}$ remains less well understood compared with other metals.

Most of these examples of metal tolerance from $\mathrm{Si}$ were performed on plants with significant $\mathrm{Si}$ accumulation. A few studies have begun to cast doubt on the view that Si must be accumulated in large amounts to provide a plant benefit. Zellner et al. (2011) documented reduced viral symptoms in nonaccumulating tobacco (Nicotiana tabacum); tomato (Solanum lycopersicum) sensitivity to salinity and blossom end rot symptoms were diminished when Si was supplied (Stamatakis et al., 2003); poinsettia (Euphorbia pulcherrima) had a longer shelf life and exhibited faster recovery from wilt when fed with $\mathrm{Si}$ during pre-production finishing (N.S. Mattson, unpublished data); tomato had induced resistance to Ralstonia solanacearum when supplemental Si was provided before and during inoculation (Ghareed et al., 2011). It should be noted that there is evidence that the extent of response and/or beneficial effects from Si may be correlated to the extent of Si uptake (Bélanger et al., 2010).

The purpose of this article is to compare the response of two species, a $\mathrm{Si}$ accumulator zinnia and a $\mathrm{Si}$ non-accumulator snapdragon, to $\mathrm{Cu}$ toxicity with and without supplemental $\mathrm{Si}$ grown in hydroponics. We examined the a priori hypothesis that supplemental $\mathrm{Si}$ would alleviate $\mathrm{Cu}$ toxicity symptoms in zinnia, but supplemental $\mathrm{Si}$ would have no effect on snapdragon as a result of differences in their ability to accumulate Si. Assessment of stress was done by documenting visible stress symptoms, dry weight, stress enzyme activity, and elemental tissue analysis.
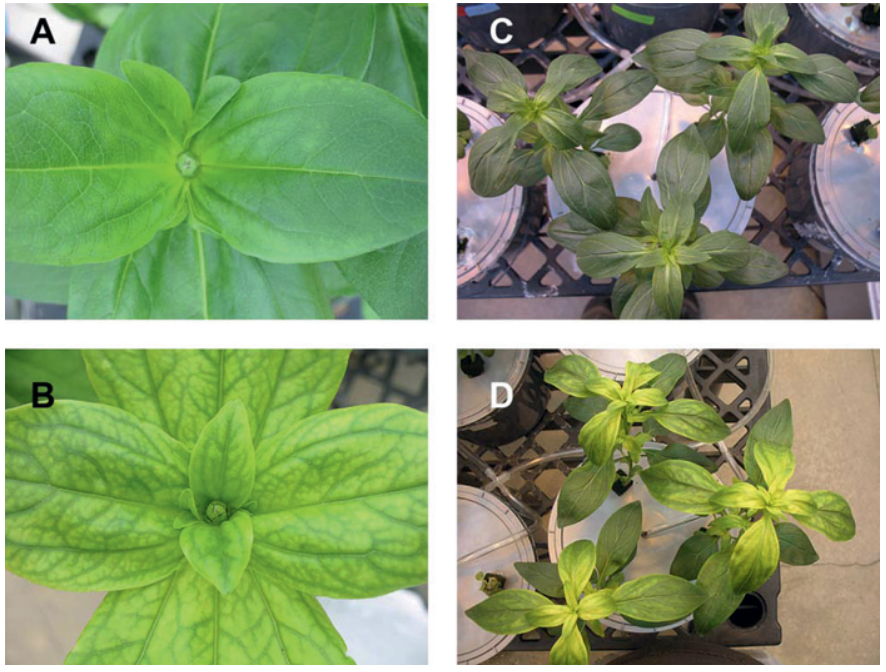

Fig. 1. Visual symptoms of zinnia and snapdragon exposed to copper $(\mathrm{Cu})$ toxicity. Control zinnia plants (A) have no yellowing in the meristem, whereas zinnia treated for 3 weeks with $50 \mu \mathrm{M} \mathrm{Cu}$ (B) exhibits interveinal chlorosis in this area, which are similar symptoms as iron deficiency. Similarly, control snapdragon plants (C) 4 weeks after transplanting have no yellowing, whereas snapdragon treated for 2 weeks with $100 \mu \mathrm{M} \mathrm{Cu}$ (D) exhibits interveinal chlorosis. Supplemental silicon did not alleviate these symptoms in snapdragon, but did in zinnia.

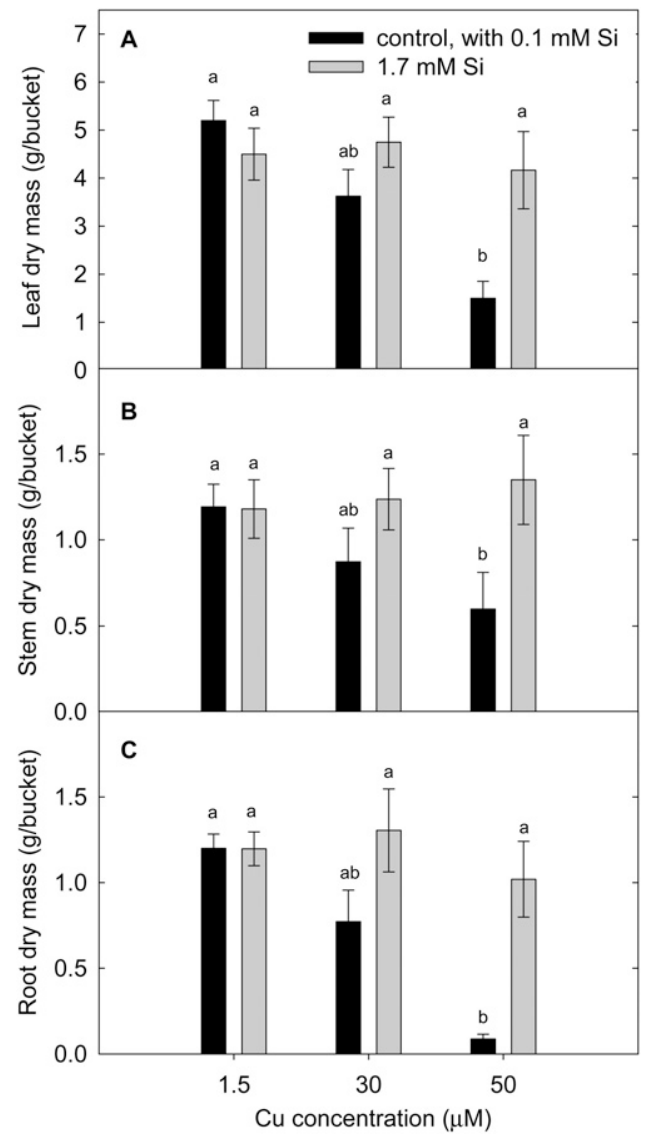

Fig. 2. Average zinnia leaf (A), stem (B), and root (C) dry mass. Plants were grown hydroponically at three different copper supplies $(1.5,30$, and $50 \mu \mathrm{M})$ and two different silicon supplies $(0.1$ and $1.7 \mathrm{~mm})$. Values are means of four replicate hydroponic buckets with each bucket containing two plants. Error bars are \pm 1 SE. Different letters above the bars within a panel indicate statistically different means based on Tukey's honest significant difference test at $P<0.05$. 


\section{Materials and Methods}

Plant growth conditions. Seedlings of zinnia ('Oklahoma White') and snapdragon ('Bedding Rocket White') were initially germinated using foam cubes $(15 \times 15 \times 30 \mathrm{~mm}$ each, LC1-type; Smithers-Oasis North America, Kent, OH). When the seedlings developed roots at the edge of the cube (time varied depending on species), they were transplanted into the lids of opaque plastic 4.5-L buckets containing aerated hydroponic solution at a planting density of three plants per tub. The solution was a modified Hoagland's solution containing $2.5 \mathrm{~mm}$ $\mathrm{KNO}_{3}, 2.5 \mathrm{~mm} \mathrm{Ca}\left(\mathrm{NO}_{3}\right)_{2}, 0.5 \mathrm{~mm} \mathrm{KH}_{2} \mathrm{PO}_{4}, 1.0 \mathrm{~mm} \mathrm{MgSO}$, $70 \mu \mathrm{M}$ Fe as Fe-DTPA, $4.5 \mu \mathrm{M} \mathrm{MnCl}_{2}, 0.75 \mu \mathrm{M} \mathrm{ZnCl}_{2}, 0.75 \mu \mathrm{M}$ $\mathrm{CuCl}_{2}, 22.5 \mu \mathrm{M} \mathrm{H}_{3} \mathrm{BO}_{3}, 0.05 \mu \mathrm{M} \mathrm{Na}_{2} \mathrm{MoO}_{4}$, and $0.1 \mathrm{~mm}$ $\mathrm{K}_{2} \mathrm{SiO}_{3}$. Silicon treatments contained an additional 1.6 or $3.3 \mathrm{mM} \mathrm{K}_{2} \mathrm{SiO}_{3}$, with the $\mathrm{Si}$ treatments beginning on transplanting seedlings into the hydroponic system. $\mathrm{K}_{2} \mathrm{SiO}_{3}$ was synthesized with fumed silica $\left(\mathrm{SiO}_{2}, 0.007 \mu \mathrm{m}\right.$ particle size) dissolved in $0.2 \mathrm{M}$ $\mathrm{KOH}$. No glassware was used in making the nutrient solution, and 18 megaohm purified water was used exclusively during the course of the trial to minimize Si contamination. The lowlevel $(0.1 \mathrm{~mm}) \mathrm{Si}$ supplied in the control solution was done to represent a more realistic situation with some $\mathrm{Si}$ present from a variety of sources such as soil, peat, perlite, lime, fertilizers, etc. found in commercial production. The $\mathrm{pH}$ of the hydroponic solution was adjusted to 5.7 with $\mathrm{H}_{2} \mathrm{SO}_{4}$ or $\mathrm{KOH}$ before nutrient solutions were added to the hydroponic containers. Solutions in the hydroponic tubs were supplemented with fresh solution daily as needed and completely replaced weekly.

$\mathrm{Cu}$ toxicity treatments began 2 weeks after transplanting into the tubs to allow for sufficient root and shoot growth for subsequent sampling. Nevertheless, insufficient root tissue was occasionally available for both zinnia and snapdragon for both total $\mathrm{Si}$ and $\mathrm{Cu}$ analysis, so $\mathrm{Cu}$ analysis was only performed in those cases. $\mathrm{Cu}$ treatments were determined based on preliminary response curves with each species. For zinnia, six different nutrient solution combinations were used including control $(1.5 \mu \mathrm{M} \mathrm{Cu}$ and $0.10 \mathrm{~mm} \mathrm{Si}$ ), + $\mathrm{Si}$ (elevated Si, $1.5 \mu \mathrm{M} \mathrm{Cu}$, and $1.7 \mathrm{~mm} \mathrm{Si}$ ), +Cu-1 (elevated $\mathrm{Cu}-1,30 \mu \mathrm{M} \mathrm{Cu}$, and $0.10 \mathrm{~mm} \mathrm{Si}$ ) and $+\mathrm{Cu}-2$ (elevated $\mathrm{Cu}-2,50 \mu \mathrm{M} \mathrm{Cu}$, and $0.1 \mathrm{~mm} \mathrm{Si}),+\mathrm{Cu}-1+\mathrm{Si}$ (elevated $\mathrm{Cu}-1$ with $\mathrm{Si}, 30 \mu \mathrm{M} \mathrm{Cu}$, and $1.7 \mathrm{~mm} \mathrm{Si}$ ), and $+\mathrm{Cu}-2+\mathrm{Si}($ elevated $\mathrm{Cu}-2$ with $\mathrm{Si}, 50 \mu \mathrm{M} \mathrm{Cu}$, and $1.7 \mathrm{~mm} \mathrm{Si}$ ) with four replications. Each replicate consisted of one hydroponic container that held three plants. The zinnia experiment was conducted twice with one set used for tissue analysis and the other set used for enzymatic assays.

For snapdragon, nine different nutrient solution combinations were used including the control $(1.5 \mu \mathrm{M} \mathrm{Cu}$ and $0.10 \mathrm{~mm}$ $\mathrm{Si}$ ), $+\mathrm{Si}-1$ (elevated $\mathrm{Si}-1,1.5 \mu \mathrm{M} \mathrm{Cu}$, and $1.7 \mathrm{mM} \mathrm{Si}$ ), $+\mathrm{Si}-2$
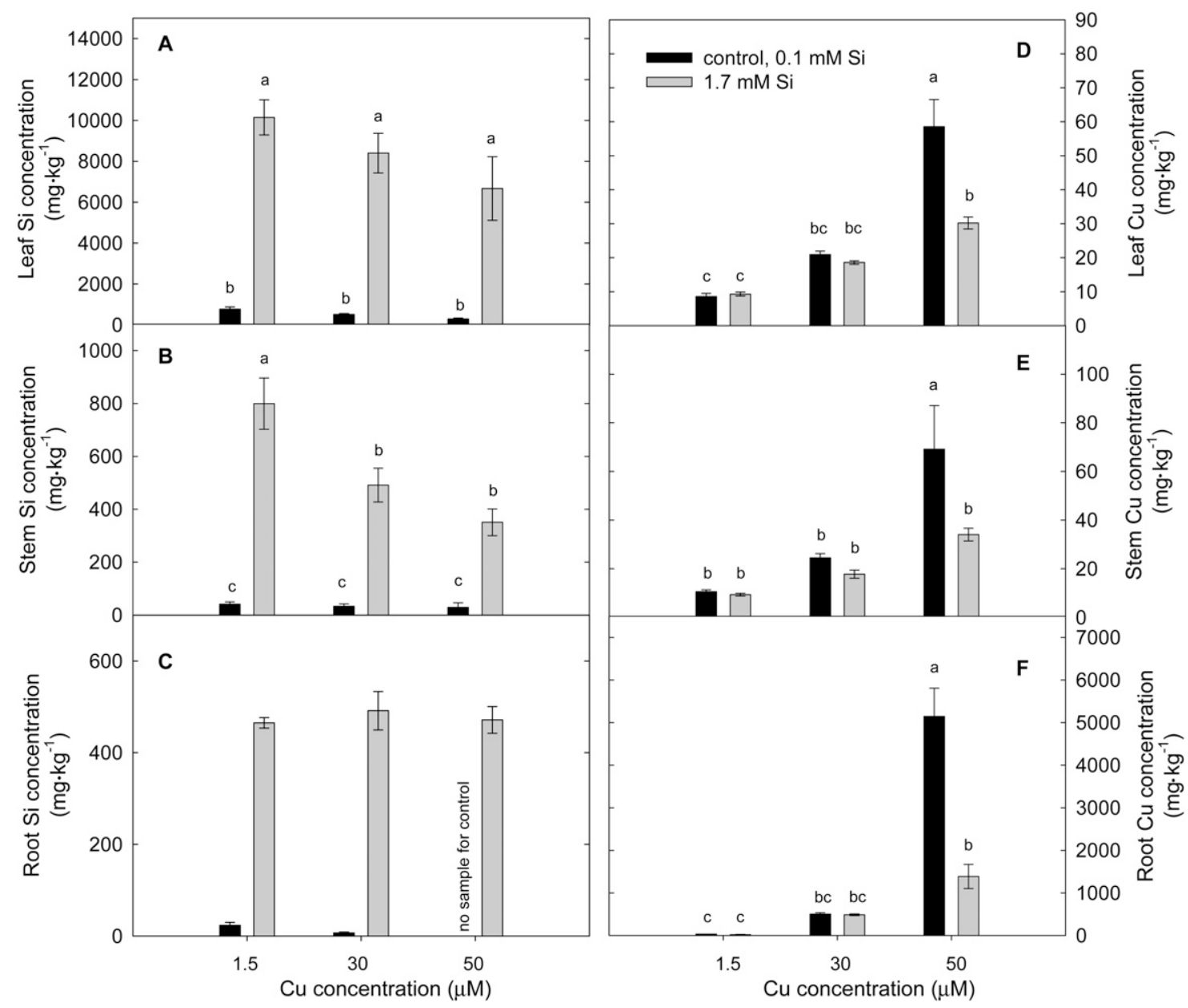

Fig. 3. Silicon concentration in zinnia leaf $(\mathbf{A})$, stem $(\mathbf{B})$, and root $(\mathbf{C})$ and copper $(\mathrm{Cu})$ concentration of zinnia leaf $(\mathbf{D})$, stem $(\mathbf{E})$, and root $(\mathbf{F})$ grown hydroponically at three different $\mathrm{Cu}$ supplies $(1.5,30$, and $50 \mu \mathrm{M})$ and two different silicon supplies $(0.1$ and $1.7 \mathrm{~mm})$. Values are means of four replicate plant groups; two plants were pooled from a single treatment hydroponic bucket and separated into leaves, stems, and roots. Error bars are \pm 1 sE. Different lowercase letters above the buckets within a panel indicate statistically different means based on Tukey's honest significant difference test at $P<0.05$. 
(elevated Si-2, 1.5 $\mu \mathrm{M} \mathrm{Cu}$, and $3.4 \mathrm{~mm} \mathrm{Si}$ ), $+\mathrm{Cu}-1$ (elevated $\mathrm{Cu}-$ $1,100 \mu \mathrm{M} \mathrm{Cu}$, and $0.10 \mathrm{~mm} \mathrm{Si}$ ) and $+\mathrm{Cu}-2$ (elevated $\mathrm{Cu}-2,150$ $\mu \mathrm{M} \mathrm{Cu}$, and 0.1 mM Si), $+\mathrm{Cu}-1+\mathrm{Si}-1$ (elevated Cu-1 with $\mathrm{Si}-1$,
$100 \mu \mathrm{M} \mathrm{Cu}$, and $1.7 \mathrm{~mm} \mathrm{Si}$ ), $+\mathrm{Cu}-1+\mathrm{Si}-2$ (elevated Cu-1 with $\mathrm{Si}-2,100 \mu \mathrm{M} \mathrm{Cu}$, and $3.4 \mathrm{mM} \mathrm{Si}$ ), $+\mathrm{Cu}-2+\mathrm{Si}-1$ (elevated $\mathrm{Cu}$ with $\mathrm{Si}-1,150 \mu \mathrm{M} \mathrm{Cu}$, and $1.7 \mathrm{mM} \mathrm{Si}$ ), and $+\mathrm{Cu}-2+\mathrm{Si}-2$ (elevated $\mathrm{Cu}-2$

Table 1. Nutrient concentrations of zinnia leaves exposed to different $\mathrm{Cu}$ and Si concentrations. ${ }^{\mathrm{z}}$

\begin{tabular}{|c|c|c|c|c|c|c|c|c|c|c|}
\hline \multicolumn{2}{|c|}{ Supply } & \multicolumn{5}{|c|}{ Macronutrients $\left(\mathrm{g} \cdot \mathrm{kg}^{-1}\right)$} & \multicolumn{4}{|c|}{ Micronutrients $\left(\mathrm{mg} \cdot \mathrm{kg}^{-1}\right)$} \\
\hline $\mathrm{Si}(\mathrm{mm})$ & $\mathrm{Cu}(\mu \mathrm{M})$ & Phosphorus & Potassium & Calcium & Magnesium & Sulfur & Boron & Iron & Manganese & Zinc \\
\hline \multirow[t]{2}{*}{0.1} & 1.5 & $9.5 \mathrm{a}^{\mathrm{y}}$ & $76.2 \mathrm{a}$ & $18.7 \mathrm{a}$ & $6.8 \mathrm{a}$ & $3.3 \mathrm{ab}$ & $70.9 \mathrm{a}$ & $106.7 \mathrm{a}$ & $366.6 \mathrm{ab}$ & $85.1 \mathrm{a}$ \\
\hline & 30 & $8.2 \mathrm{ab}$ & $73.6 \mathrm{a}$ & $19.5 \mathrm{a}$ & $7.0 \mathrm{a}$ & $3.6 \mathrm{a}$ & 83.9 a & $105.9 \mathrm{a}$ & $423.1 \mathrm{a}$ & $74.8 \mathrm{ab}$ \\
\hline \multirow[t]{2}{*}{1.7} & 1.5 & $10.2 \mathrm{a}$ & $73.4 \mathrm{a}$ & $19.5 \mathrm{a}$ & $5.9 \mathrm{a}$ & $3.5 \mathrm{ab}$ & $70.3 \mathrm{a}$ & $83.0 \mathrm{ab}$ & $369.7 \mathrm{ab}$ & $67.0 \mathrm{ab}$ \\
\hline & 30 & $8.9 \mathrm{ab}$ & $77.4 \mathrm{a}$ & $20.2 \mathrm{a}$ & $6.3 \mathrm{a}$ & $3.6 \mathrm{a}$ & $74.1 \mathrm{a}$ & $96.2 \mathrm{ab}$ & $385.4 \mathrm{a}$ & $76.0 \mathrm{ab}$ \\
\hline \multirow[t]{3}{*}{$P$ value } & $\mathrm{Cu}$ & 0.0001 & 0.0001 & 0.0558 & 0.0001 & 0.1648 & 0.3021 & 0.0073 & 0.0001 & 0.0001 \\
\hline & $\mathrm{Si}$ & 0.0059 & 0.0045 & 0.0025 & 0.7368 & 0.0057 & 0.7530 & 0.9311 & 0.0537 & 0.4021 \\
\hline & $\mathrm{Cu} \times \mathrm{Si}$ & 0.1249 & 0.0012 & 0.0039 & 0.0031 & 0.0425 & 0.1619 & 0.0771 & 0.0027 & 0.0081 \\
\hline
\end{tabular}

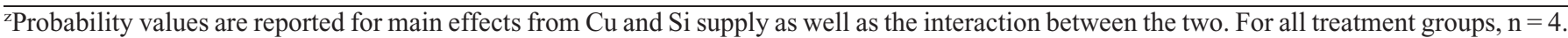
${ }^{y}$ Different letters within a column indicates significant differences in means from other treatments for that nutrient based on Tukey's honest significant differences test at $P<0.05$.

$\mathrm{Cu}=$ copper; $\mathrm{Si}=$ silicon.

Table 2. Nutrient concentrations of zinnia roots exposed to different $\mathrm{Cu}$ and Si concentrations. ${ }^{\mathrm{z}}$

\begin{tabular}{|c|c|c|c|c|c|c|c|c|c|c|}
\hline \multicolumn{2}{|c|}{ Supply } & \multicolumn{5}{|c|}{ Macronutrients $\left(\mathrm{g} \cdot \mathrm{kg}^{-1}\right)$} & \multicolumn{4}{|c|}{ Micronutrients $\left(\mathrm{mg} \cdot \mathrm{kg}^{-1}\right)$} \\
\hline Si (mM) & $\mathrm{Cu}(\mu \mathrm{M})$ & Phosphorus & Potassium & Calcium & Magnesium & Sulfur & Boron & Iron & Manganese & Zinc \\
\hline \multirow[t]{2}{*}{0.1} & 1.5 & $9.0 \mathrm{a}^{\mathrm{y}}$ & $121.5 \mathrm{a}$ & $6.0 \mathrm{bc}$ & $3.5 \mathrm{ab}$ & $8.7 \mathrm{a}$ & $25.2 \mathrm{a}$ & $2356.3 \mathrm{~b}$ & $944.8 \mathrm{ab}$ & $45.5 \mathrm{~b}$ \\
\hline & 30 & $8.4 \mathrm{a}$ & $99.2 \mathrm{a}$ & $6.4 \mathrm{bc}$ & $2.9 \mathrm{~b}$ & $5.9 \mathrm{ab}$ & $24.2 \mathrm{ab}$ & $2393.7 \mathrm{~b}$ & $853.0 \mathrm{bc}$ & $73.8 \mathrm{ab}$ \\
\hline \multirow[t]{2}{*}{1.7} & 1.5 & $8.8 \mathrm{a}$ & $112.5 \mathrm{a}$ & $5.8 \mathrm{c}$ & $4.9 \mathrm{a}$ & $7.9 \mathrm{ab}$ & $26.9 \mathrm{a}$ & $1483.9 \mathrm{~b}$ & $1313.1 \mathrm{a}$ & $40.8 \mathrm{~b}$ \\
\hline & 30 & $8.4 \mathrm{a}$ & $114.5 \mathrm{a}$ & $7.2 \mathrm{ab}$ & $3.2 \mathrm{~b}$ & $8.7 \mathrm{a}$ & $28.2 \mathrm{a}$ & $1735.9 \mathrm{~b}$ & $827.3 \mathrm{bc}$ & $83.6 \mathrm{a}$ \\
\hline \multirow[t]{3}{*}{$P$ value } & $\mathrm{Cu}$ & 0.4012 & 0.0001 & 0.0001 & 0.0007 & 0.0026 & 0.0023 & 0.0002 & 0.0001 & 0.0001 \\
\hline & $\mathrm{Si}$ & 0.9113 & 0.0227 & 0.0105 & 0.0036 & 0.0470 & 0.0074 & 0.0211 & 0.0031 & 0.5356 \\
\hline & $\mathrm{Cu} \times \mathrm{Si}$ & 0.8986 & 0.0123 & 0.0432 & 0.2569 & 0.0310 & 0.3252 & 0.1091 & 0.0520 & 0.6586 \\
\hline
\end{tabular}

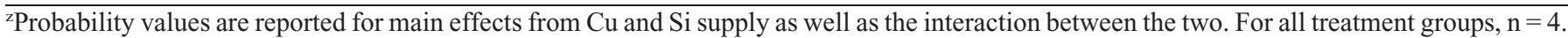
${ }^{y}$ Different letters within a column indicates significant differences in means from other treatments for that nutrient based on Tukey's honest significant differences test at $P<0.05$.

$\mathrm{Cu}=$ copper; $\mathrm{Si}=$ silicon.

Table 3. Nutrient concentrations of zinnia stem exposed to different $\mathrm{Cu}$ and $\mathrm{Si}$ concentrations. ${ }^{\mathrm{z}}$

\begin{tabular}{|c|c|c|c|c|c|c|c|c|c|c|}
\hline \multicolumn{2}{|c|}{ Supply } & \multicolumn{5}{|c|}{ Macronutrients $\left(\mathrm{g} \cdot \mathrm{kg}^{-1}\right)$} & \multicolumn{4}{|c|}{ Micronutrients $\left(\mathrm{mg} \cdot \mathrm{kg}^{-1}\right)$} \\
\hline $\mathrm{Si}(\mathrm{mm})$ & $\mathrm{Cu}(\mu \mathrm{M})$ & Phosphorus & Potassium & Calcium & Magnesium & Sulfur & Boron & Iron & Manganese & Zinc \\
\hline \multirow[t]{2}{*}{0.1} & 1.5 & $8.7 \mathrm{ab}^{\mathrm{y}}$ & $73.8 \mathrm{a}$ & $9.1 \mathrm{~b}$ & $3.3 \mathrm{a}$ & $2.0 \mathrm{a}$ & $20.4 \mathrm{~b}$ & $80.2 \mathrm{ab}$ & $82.8 \mathrm{ab}$ & $52.2 \mathrm{a}$ \\
\hline & 30 & $7.6 \mathrm{bc}$ & $71.6 \mathrm{a}$ & $8.8 \mathrm{~b}$ & $3.7 \mathrm{a}$ & $2.4 \mathrm{a}$ & $22.5 \mathrm{~b}$ & $57.3 \mathrm{~b}$ & $155.5 \mathrm{a}$ & $48.3 \mathrm{a}$ \\
\hline \multirow[t]{2}{*}{1.7} & 1.5 & $10.2 \mathrm{a}$ & $74.8 \mathrm{a}$ & $10.4 \mathrm{a}$ & $3.5 \mathrm{a}$ & $2.3 \mathrm{a}$ & $24.9 \mathrm{ab}$ & $102.5 \mathrm{a}$ & $133.9 \mathrm{ab}$ & $57.6 \mathrm{a}$ \\
\hline & 30 & $7.7 \mathrm{abc}$ & $71.6 \mathrm{a}$ & $10.2 \mathrm{a}$ & $3.1 \mathrm{a}$ & $2.2 \mathrm{a}$ & $23.5 \mathrm{~b}$ & $64.2 \mathrm{~b}$ & $123.1 \mathrm{ab}$ & $50.6 \mathrm{a}$ \\
\hline \multirow[t]{3}{*}{$P$ value } & $\mathrm{Cu}$ & 0.0001 & 0.0001 & 0.6559 & 0.9999 & 0.7032 & 0.0119 & 0.0333 & 0.0035 & 0.5324 \\
\hline & $\mathrm{Si}$ & 0.0149 & 0.0134 & 0.0182 & 0.3296 & 0.2525 & 0.7633 & 0.1908 & 0.3735 & 0.0790 \\
\hline & $\mathrm{Cu} \times \mathrm{Si}$ & 0.2746 & 0.0068 & 0.9073 & 0.3711 & 0.1428 & 0.0018 & 0.7172 & 0.0719 & 0.2892 \\
\hline
\end{tabular}

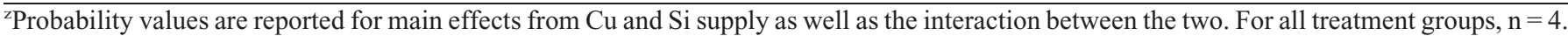
${ }^{y}$ Different letters within a column indicates significant differences in means from other treatments for that nutrient based on Tukey's honest significant differences test at $P<0.05$.

$\mathrm{Cu}=$ copper; $\mathrm{Si}=$ silicon. 
with $\mathrm{Si}-2,150 \mu \mathrm{M} \mathrm{Cu}$, and $3.4 \mathrm{mM} \mathrm{Si}$ ). The snapdragon experiment was conducted four times. Although all four experiments showed similar responses, data from only one representative study are shown for simplicity. In this study, a single plant in each bucket was harvested for enzymatic assays, whereas the remaining two plants in each pot were harvested for elemental and dry weight analysis. The plants collected from a single bucket were considered to be a single replicate for enzymatic assays and a single replicate for dry weight and elemental analysis.

Harvesting AND ASSAYs. After 2 weeks (zinnia) or 3 weeks (snapdragon) of treatment, leaves, stems (combined as "shoots" for enzymatic assays), and roots were harvested, rinsed with distilled water, blotted dry, and fresh weight was determined. For elemental and dry weight analysis, tissue was dried in a forced-air oven at $55^{\circ} \mathrm{C}$ for $3 \mathrm{~d}$ and used for tissue analysis as described subsequently. For other tests, tissue was immediately frozen in liquid nitrogen and stored at $-80^{\circ} \mathrm{C}$ for subsequent use. Phenylalanine ammonia lyase [PAL (EC 4.3.1.5)] activity was measured by the method described in Liang et al. (2005) with some modifications described in Li et al. (2008). Peroxidase [POD (EC 1.11.1.7)] activity was measured by the method described in Liang et al. (2005).

Elemental analyses were performed according Frantz et al. (2008) and are briefly described here. For total tissue Si quantification, $0.15 \mathrm{~g}$ ground tissue or substrate material was digested in $7.5 \mathrm{M} \mathrm{KOH}$ in a programmable microwave (MARS Express; CEM Corp., Matthews, NC). One milliliter of the digested solution was diluted with $9 \mathrm{~mL}$ deionized water (18 megaohm purity) and injected into the inductively coupled plasma optical emission spectroscopy [ICP-OES (Model IRIS Intrepid II; Thermo Electron Corp., Waltham, MA)]. Every 20 samples, a rice (Oryza sativa) standard containing $0.44 \% \mathrm{Si}$ was run that had been digested in a similar manner as the test species. For other elemental analysis, the same quantity of tissue was digested as according to Li et al. (2008) and briefly described here. A modified U.S. Environmental Protection Agency [EPA method 3051 (Nelson, 1988); $\mathrm{HNO}_{3}$ digestion at $200{ }^{\circ} \mathrm{C}$ with an additional peroxide digestion step] was used for total nutrient concentrations for phosphorus, potassium, calcium, sulfur, magnesium, boron, $\mathrm{Cu}, \mathrm{Fe}, \mathrm{Mn}$, and $\mathrm{Zn}$ from ICP-OES. Total nitrogen was not analyzed. In the set of samples for zinnia root tissue receiving no supplemental $\mathrm{Si}$ at the highest $\mathrm{Cu}$ rate, not enough tissue was available for $\mathrm{Si}$ analysis.

STATistics. Data were subjected to two-way analysis of variance using the statistical software (Statistix Version 9.0; Analytical Software, Tallahassee, FL) with $\mathrm{Cu}$ and $\mathrm{Si}$ supply as the main effects and a $\mathrm{Cu} \times \mathrm{Si}$ interaction. If significance was determined $(P<0.05)$, Tukey's honest significant difference (HSD) test of means was performed to determine potential differences among group means. No statistical comparisons were made between species, but observations of each species were used to speculate about mechanism of action for $\mathrm{Si}$ alleviating $\mathrm{Cu}$ toxicity stress symptoms.

\section{Results and Discussion}

VisibLE SYMPTOMS. In both species, as plants received more $\mathrm{Cu}$ with low $(0.1 \mathrm{~mm}) \mathrm{Si}$, root tips changed from white to tan, brown, or deep orange (root photographs not shown). Leaves and shoots of $\mathrm{Cu}$-toxicity treatment plants not receiving supplemental Si were often stunted and displayed interveinal chlorosis reminiscent of Fe deficiency (Fig. 1A-D). Bucher and Schenk (2000) reported that $\mathrm{Cu}$ toxicity symptoms can be alleviated, at least temporarily, with Fe additions, which would

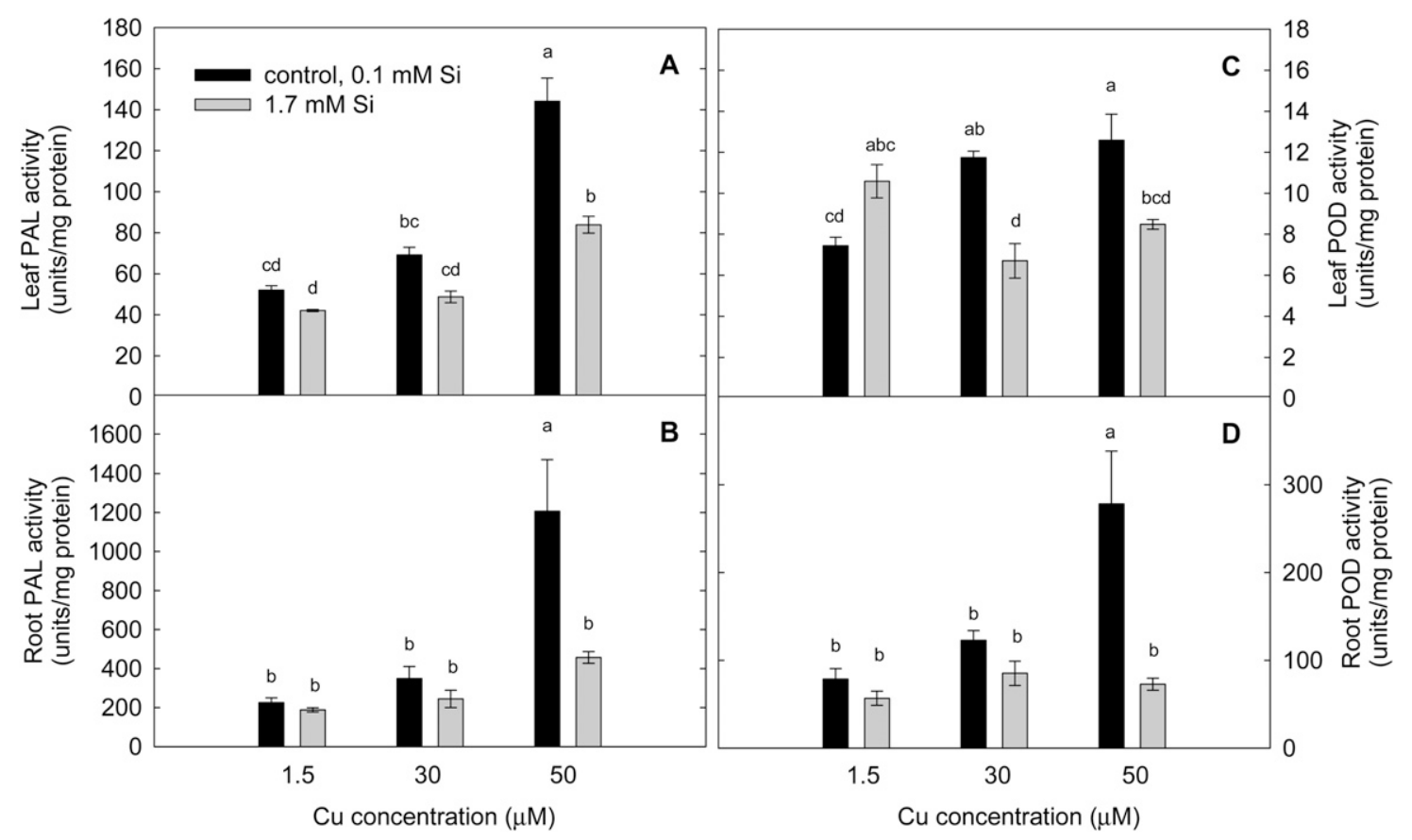

Fig. 4. Average phenylalanine ammonia lyase (PAL) activity of zinnia shoots (A) and roots (B) and average peroxidase (POD) activity of zinnia shoots (C) and roots (D) with $\pm 1 \mathrm{SE}$. Plants were grown hydroponically at three different copper supplies $(1.5,30$, and $50 \mu \mathrm{M})$ and two different silicon supplies $(0.1$ and $1.7 \mathrm{~mm})$. A representative plant was harvested from each hydroponic bucket so values are averages of four plants in each treatment. Different lowercase letters above the bars within a panel indicate statistically different means based on Tukey's honest significant difference test at $P<0.05$. 
certainly confuse the diagnosis of $\mathrm{Cu}$ toxicity problems. It is this set of symptoms and the response to Fe supplementation that leads us to believe that $\mathrm{Cu}$ toxicity may be more widely encountered than currently reported. In control $\mathrm{Cu}$ conditions, root appearance was unaffected by the addition of $\mathrm{Si}$.

For zinnia, as Si was added to treatments also exposed to $\mathrm{Cu}$ toxicity, the occurrence of discolored roots diminished, suggesting at least partial alleviation of $\mathrm{Cu}$ toxicity symptoms. This response was similar to that observed in arabidopsis ( $\mathrm{Li}$ et al., 2008). For snapdragon, supplemental Si had no effect on the reduction of visible stress symptoms on any part of the plant.

ZinNiA. Dry weight of leaves, stems, and roots diminished as $\mathrm{Cu}$ concentration increased in non-Si-supplemented treatments (Fig. 2A-C). Dry weight was significantly greater in leaves, stems, and roots of plants receiving supplemental $\mathrm{Si}$ when $\mathrm{Cu}$ was $50 \mu \mathrm{M}$. The dry weight of the leaves, stems, and roots of high $\mathrm{Cu}$ treatments that also received supplemental Si was not statistically different from control tissue.

Leaf, stem, and root Si concentration was significantly greater when supplemental $\mathrm{Si}$ was provided to plants (Fig. $3 \mathrm{~A}-\mathrm{C}$ ). $\mathrm{Cu}$ concentrations of those tissues was also influenced by $\mathrm{Cu}$ and $\mathrm{Si}$ supply (Fig. 3D-F). As expected, $\mathrm{Cu}$ increased with increasing $\mathrm{Cu}$ supply; however, at the highest $\mathrm{Cu}$ supply, concentration of the metal did not increase as much as when Si was also present. This indicates that $\mathrm{Si}$ prevented $\mathrm{Cu}$ from accumulating in the tissue at the same extent as unsupplemented plants. In arabidopsis, Si was shown to alter the expression pattern of genes related to metal uptake and distribution ( $\mathrm{Li}$ et al., 2008). Interestingly, $\mathrm{Cu}$ concentration was unaffected in shoots and roots of arabidopsis despite those mechanistic changes. The different response of arabidopsis and zinnia to $\mathrm{Cu}$ concentration in response to $\mathrm{Cu}$ toxicity with and without $\mathrm{Si}$ supplementation suggests that the Si-mediated mechanism is different among species.

Concentrations of other nutrients were also influenced by $\mathrm{Si}$ and $\mathrm{Cu}$ (Tables 1-3). All nutrient concentrations in one or more tissue types were significantly influenced, either as a main effect or an interactive effect, by $\mathrm{Si}$. The concentrations of potassium (K) and calcium $(\mathrm{Ca})$ were the only nutrients to be significantly influenced in all three tissues by Si. Some effects can be explained by the additional $\mathrm{K}$ present in Si-supplemented treatments; K was higher in Si-supplemented treatments, and the effect was more pronounced in the highest $\mathrm{Cu}$ treatment. One would expect for Ca to be suppressed when high levels of $\mathrm{K}$ are present as a result of competitive, antagonistic effects from positively charged ions. This was not the case because $\mathrm{Ca}$ concentrations were occasionally higher (as in stem) in Sisupplemented treatments. In general, nutrient concentration differences were most likely because plants that received Si supplementation were generally healthier (less stressed) when grown at the highest $\mathrm{Cu}$ treatment compared with unsupplemented, $\mathrm{Cu}$-toxic treatments.

Leaf PAL activity of both control $(1.5 \mu \mathrm{M} \mathrm{Cu})$ and plants treated with elevated $\mathrm{Si}(1.5 \mu \mathrm{M} \mathrm{Cu}$ and $1.7 \mathrm{~mm} \mathrm{Si})$ was nearly the same (Fig. 4A-B). The same was true for roots of those treatments. Zinnia treated with $30 \mu \mathrm{M} \mathrm{Cu}$ showed a slight increase, although not statistically significant, in both leaf and root PAL activity from average levels in control treatments. Both leaves and roots of zinnia treated with $50 \mu \mathrm{M} \mathrm{Cu}$ showed more dramatic increases in PAL activity that was reduced by addition of extra $\mathrm{Si}$. Hence, $\mathrm{Si}$ application results in a reduction in $\mathrm{Cu}$-induced PAL activity in zinnia roots and shoots. Such data probably indicate that the leaves in plants supplemented with $\mathrm{Si}$ grown under elevated $\mathrm{Cu}$ conditions are under less stress than unsupplemented plants. Perhaps Si helps generate additional apoplastic $\mathrm{Cu}$-binding sites, sequestering the metal and thereby reducing its toxic effects as has been suggested for Mn (Iwasaki et al., 2002a, 2002b, 2002c; Rogalla and Römheld, 2002).

The POD data are similar to those for PAL (Fig. 4C-D). POD activity in leaves and roots was elevated by increased $\mathrm{Cu}$ and this was reduced by an additional high level of Si. For both leaves and roots, elevated $\mathrm{Cu}$ caused an increase in POD activity that was depressed by the additional high level of Si. $\mathrm{Cu}$ toxicity increases POD activity in maize (Zea mays) seedlings (Mocquot et al., 1996). These researchers proposed that $\mathrm{Cu}$ toxicity induces the formation of active oxygen species, which induces POD production to detoxify these highly reactive molecules. If this is also the case for other plants, then $\mathrm{Si}$ may cause a reduction in active oxygen species production, thereby reducing $\mathrm{POD}$ expression. If $\mathrm{Si}$ induces more $\mathrm{Cu}$ binding sites in the cell wall, it is possible that the metal is sequestered away from the plant cell interior, reducing the formation of reactive oxygen species, again leading to a reduction in POD activity. Alternatively, Si may have an effect on

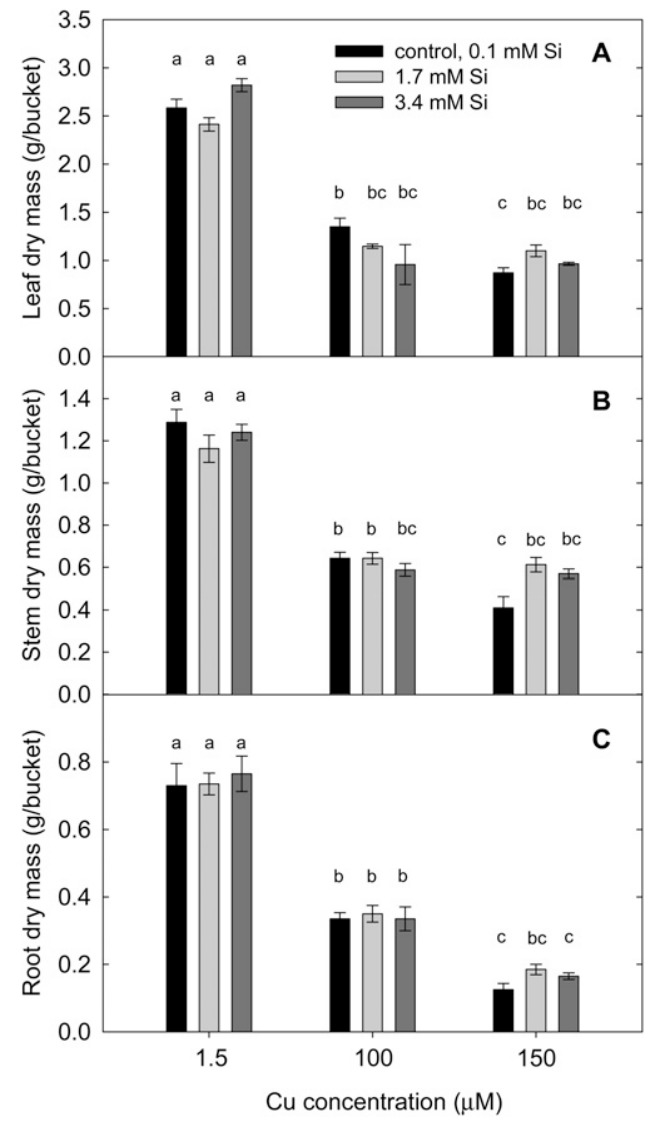

Fig. 5. Average snapdragon leaf (A), stem (B), and root (C) dry mass. Treatments consisted of low $(0.1 \mathrm{~mm})$, medium $(1.7 \mathrm{~mm})$, and high $(3.4$ mм) supplemental silicon and 3 weeks after exposure to control (1.5 $\mu \mathrm{M})$, medium $(100 \mu \mathrm{M})$, and high $(150 \mu \mathrm{M})$ copper. Values are means of four replicate hydroponic buckets with each bucket containing two plants. Error bars are \pm 1 SE. Different lowercase letters above the bars within a panel indicate statistically different means based on Tukey's honest significant difference at $P<0.05$. 
POD gene expression or enzyme activity independent of reducing the production of active oxygen species.

Snapdragon. Cu toxicity significantly decreased leaf, stem, and root mass (Fig. 5A-C). The extent of dry matter decrease was slightly, yet statistically significant, different as $\mathrm{Cu}$ concentration increased with and without Si supplementation. This led to a significant interaction between $\mathrm{Cu}$ and $\mathrm{Si}$, although Tukey's test of means for a given $\mathrm{Cu}$ concentration resulted in no differences in mean tissue mass. So although statistically significant, the visible symptoms combined with dry matter analysis revealed little, if any, biological benefit provided by supplemental Si.

The concentration of $\mathrm{Si}$ increased with $\mathrm{Si}$ supplementation in snapdragon in leaves, but to a far lower extent than zinnia (Fig. 6A). Interestingly, Si concentration in leaves increased as $\mathrm{Cu}$ supply increased. A similar observation was made by Zellner et al. (2011), where it was hypothesized that tobacco (also a non-accumulator) leaves can regulate $\mathrm{Si}$ uptake in response to biotic stress. That is, in some plants, Si uptake may be stimulated by stress, thereby enabling the plant to make use of the element in stress alleviation. Stem analysis revealed mostly non-detectable Si concentrations regardless of treatment (data not shown). Additionally, there was insufficient root biomass for both total $\mathrm{Si}$ and all other elemental analysis for many of the replicate plants, so total Si data are not shown for roots.

$\mathrm{Cu}$ increased in all tissues as $\mathrm{Cu}$ supply increased (Fig. 6BD). The extent of that increase was modulated by Si supply and was different for leaves, stems, and roots. In both leaves and stems, there was a significant interaction between $\mathrm{Cu}$ and $\mathrm{Si}$ with $\mathrm{Si}$ suppressing slightly the extent of increased $\mathrm{Cu}$ accumulation; the Tukey's HSD test did not indicate any significant differences within a $\mathrm{Cu}$ supply. Root $\mathrm{Cu}$ concentrations were significantly influenced by $\mathrm{Si}$ both as an interaction with $\mathrm{Cu}$ and as a main effect. At the highest $\mathrm{Cu}$ supply (150 $\mu \mathrm{M}), \mathrm{Si}$ increasingly suppressed tissue $\mathrm{Cu}$ concentration with the $3.4 \mathrm{~mm}$ Si concentration resulting in significantly lower $\mathrm{Cu}$ in the root than the unsupplemented ( $0.1 \mathrm{~mm}$ Si supply), high $\mathrm{Cu}$ treatment. As a main effect, both $\mathrm{Si}$ supplies (1.7 and $3.4 \mathrm{~mm} \mathrm{Si}$ ) resulted in significantly lower $\mathrm{Cu}$ concentrations than unsupplemented plants $(0.1 \mathrm{~mm} \mathrm{Si})$. Although the extent of suppressing $\mathrm{Cu}$ uptake was not as great as that observed in zinnia, the mechanism of $\mathrm{Si}$ potentially influencing $\mathrm{Cu}$ toxicity appears more like zinnia than arabidopsis (Li et al., 2008) based solely on tissue analysis data.

All other nutrients tested were influenced by $\mathrm{Si}$ either as a direct or interactive effect (Tables 4-6). In general, the greater the Si supply during $\mathrm{Cu}$ toxicity, the more similar that tissue's nutrient concentrations were to the concentrations of control plants. This is evidence that overall nutrient uptake was less impacted by $\mathrm{Cu}$ toxicity when $\mathrm{Si}$ was also present in sufficient quantities than when $\mathrm{Si}$ was lacking. Interestingly, root tissue concentrations were less influenced by the presence of Si than either shoot tissue despite being washed with $\mathrm{Si}$; the shoot tissue concentrations are indications that uptake was functioning better in $\mathrm{Si}$-amended solutions than unamended solutions when $\mathrm{Cu}$ was at toxic levels. Iron levels in snapdragon leaves were significantly decreased at both $\mathrm{Cu}$ concentrations and they were not significantly affected by $\mathrm{Si}$ supplementation. This would agree with the symptom data in which $\mathrm{Cu}$-treated plants showed leaf chlorosis similar to Fe deficiency that was not reversed by $\mathrm{Si}$ application.

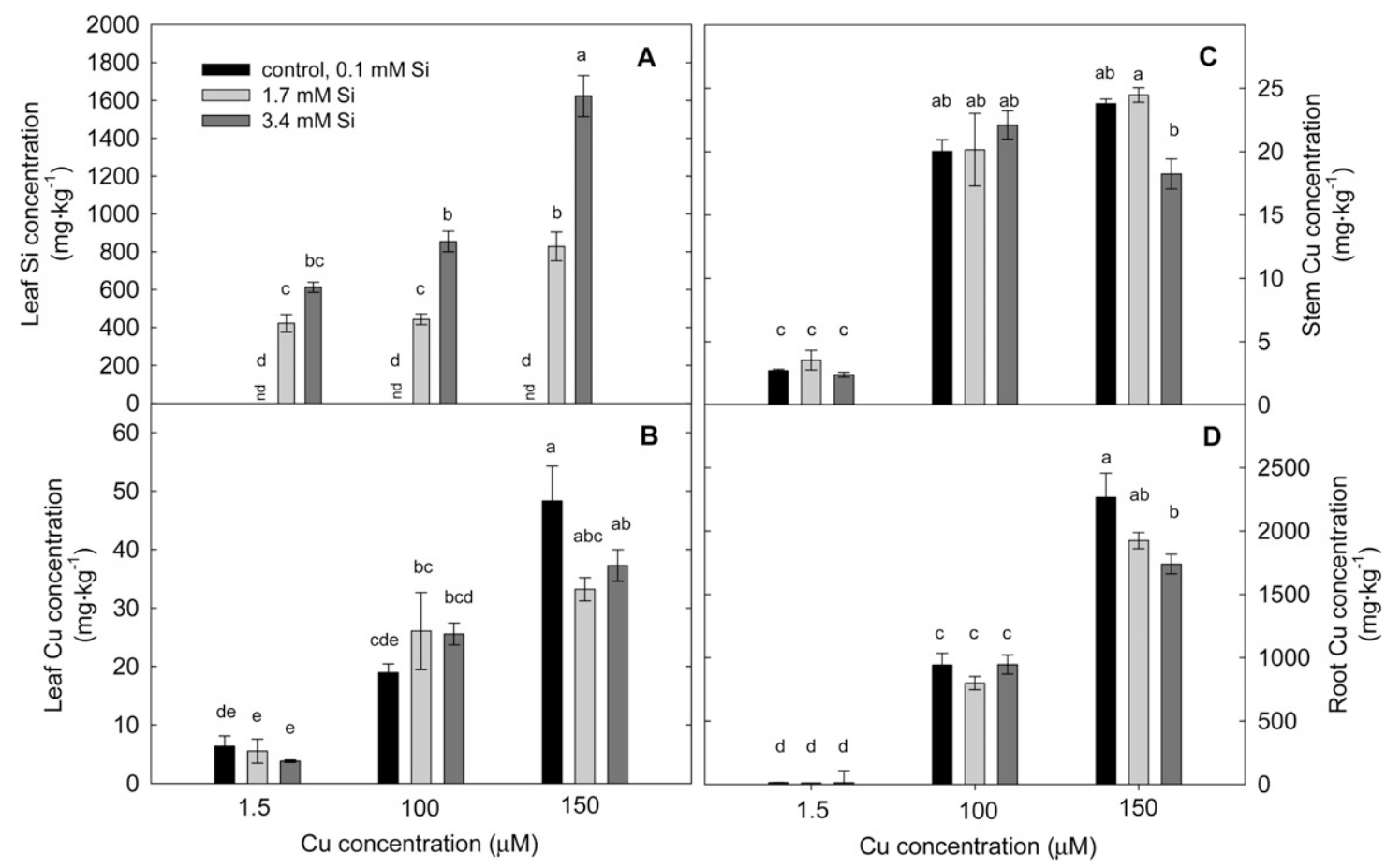

Fig. 6. Leaf silicon $(\mathrm{Si})$ concentration $(\mathbf{A})$, and copper $(\mathrm{Cu})$ concentration in leaf $(\mathbf{B})$, stem $(\mathbf{C})$, and root $(\mathbf{D})$ of snapdragon harvested 5 weeks after transplanting seedlings into a hydroponic system containing low $(0.1 \mathrm{~mm})$, medium $(1.7 \mathrm{mM})$, and high $(3.4 \mathrm{mM})$ supplemental Si and 3 weeks after exposure to control (1.5 $\mu \mathrm{M})$, medium $(100 \mu \mathrm{M})$, and high $(150 \mu \mathrm{M}) \mathrm{Cu}$. Error bars are $\pm 1 \mathrm{SE}$, whereas different lowercase letters above the bars within a panel indicate statistically different means based on Tukey's honest significant difference test at $P<0.05$. Leaf Si concentration was not measured above background levels, so nd $=$ not detectable in those treatments. A value of $0.1 \mathrm{mg} \cdot \mathrm{kg}^{-1}$ was inserted in those replicates for statistical purposes. 
PAL activity was higher in both roots and shoots as copper supply increased (Fig. 7A-B). This indicated the plant experienced greater levels of stress and increased stress response accordingly. Root tissue was unaffected by $\mathrm{Si}$ addition either directly or as an interactive effect. This was similar to the minimal effect that Si had on nutrient concentrations in the root tissue. Leaf PAL activity was significantly influenced by Si. As Si levels increased, PAL activity decreased indicating the stress was minimized with supplemental Si treatment. The extent of the minimization depended on $\mathrm{Cu}$ supply with both $\mathrm{Cu}$ toxicity levels responding with less PAL activity at higher Si supply rates than control levels of $\mathrm{Cu}$, in which PAL activity was unchanged across all Si supply rates.

ACCumulators versus nON-ACCUMUlators. Our a priori hypothesis that supplemental $\mathrm{Si}$ does nothing in snapdragon plants experiencing $\mathrm{Cu}$ toxicity because it is not a Si accumulator and is not supported by our experimental data. The observed response could best be described as muted in snapdragon, but $\mathrm{Si}$ clearly had a measurable effect on overall stress response and plant health as measured by stress enzyme activity and nutrient status. With observations on poinsettia (N.S. Mattson, unpublished data), tomato (Stamatakis et al., 2003), tobacco (Zellner et al., 2011), and now snapdragon (all so-called non-accumulators) clearly being influenced by the presence of Si during specific stress events, we should instead focus on the extent of response from $\mathrm{Si}$, not if $\mathrm{Si}$ can induce a response.

These data on Si uptake potential for various crops suggest that plants use different mechanisms to accomplish specific tasks. In the case of these two plants, Si-accumulating zinnia is more effective at using this element, perhaps by generating

Table 4. Nutrient concentrations of snapdragon leaves exposed to different $\mathrm{Cu}$ and Si concentrations. ${ }^{\mathrm{z}}$

\begin{tabular}{|c|c|c|c|c|c|c|c|c|c|c|}
\hline \multicolumn{2}{|c|}{ Supply } & \multicolumn{5}{|c|}{ Macronutrients $\left(\mathrm{g} \cdot \mathrm{kg}^{-1}\right)$} & \multicolumn{4}{|c|}{ Micronutrients $\left(\mathrm{mg} \cdot \mathrm{kg}^{-1}\right)$} \\
\hline $\mathrm{Si}(\mathrm{mm})$ & $\mathrm{Cu}(\mu \mathrm{M})$ & Phosphorus & Potassium & Calcium & Magnesium & Sulfur & Boron & Iron & Manganese & Zinc \\
\hline \multirow[t]{2}{*}{0.1} & 1.5 & $11.9 \mathrm{a}^{\mathrm{y}}$ & $72.2 \mathrm{ab}$ & $19.1 \mathrm{ab}$ & $14.5 \mathrm{a}$ & $4.6 \mathrm{~b}$ & $32.8 \mathrm{abc}$ & $97.4 \mathrm{a}$ & $173.4 \mathrm{~b}$ & $25.3 \mathrm{bcd}$ \\
\hline & 100 & $11.4 \mathrm{a}$ & $58.3 \mathrm{~cd}$ & $21.0 \mathrm{a}$ & $12.6 \mathrm{~b}$ & $5.4 \mathrm{a}$ & $37.1 \mathrm{ab}$ & $38.5 \mathrm{c}$ & $394.8 \mathrm{a}$ & $31.1 \mathrm{abc}$ \\
\hline \multirow[t]{2}{*}{1.7} & 1.5 & $11.5 \mathrm{a}$ & $73.1 \mathrm{a}$ & $20.1 \mathrm{ab}$ & $12.4 \mathrm{bc}$ & $4.6 \mathrm{~b}$ & $32.0 \mathrm{bc}$ & $99.8 \mathrm{a}$ & $212.9 \mathrm{~b}$ & $29.3 \mathrm{abcd}$ \\
\hline & 100 & $12.1 \mathrm{a}$ & $54.3 \mathrm{~d}$ & $22.9 \mathrm{a}$ & $11.0 \mathrm{~cd}$ & $5.4 \mathrm{a}$ & $40.1 \mathrm{a}$ & $66.5 \mathrm{bc}$ & $380.1 \mathrm{a}$ & $34.7 \mathrm{a}$ \\
\hline \multirow[t]{3}{*}{3.4} & 1.5 & $11.2 \mathrm{a}$ & $75.6 \mathrm{a}$ & $16.9 \mathrm{bc}$ & $11.4 \mathrm{bcd}$ & $4.3 \mathrm{~b}$ & $27.8 \mathrm{~cd}$ & $86.7 \mathrm{ab}$ & $243.7 \mathrm{~b}$ & $25.2 \mathrm{bcd}$ \\
\hline & 100 & $11.9 \mathrm{a}$ & $65.2 \mathrm{bc}$ & $19.6 \mathrm{ab}$ & $10.5 \mathrm{~d}$ & $5.8 \mathrm{a}$ & $36.7 \mathrm{ab}$ & $48.0 \mathrm{c}$ & $366.3 \mathrm{a}$ & $33.1 \mathrm{ab}$ \\
\hline & 150 & $8.3 \mathrm{~b}$ & $43.7 \mathrm{e}$ & $15.1 \mathrm{~cd}$ & $4.9 \mathrm{e}$ & $3.3 \mathrm{c}$ & $33.4 \mathrm{abc}$ & $46.7 \mathrm{c}$ & $75.7 \mathrm{c}$ & $29.8 \mathrm{abcd}$ \\
\hline$P$ value & $\mathrm{Cu}$ & 0.0001 & 0.0001 & 0.0001 & 0.0001 & 0.0001 & 0.0001 & 0.0001 & 0.0001 & 0.0001 \\
\hline
\end{tabular}

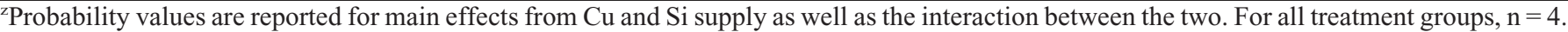
${ }^{y}$ Different letters within a column indicates significant differences in means from other treatments for that nutrient based on Tukey's honest significant differences test at $P<0.05$.

$\mathrm{Cu}=$ copper; $\mathrm{Si}=$ silicon.

Table 5. Nutrient concentrations of snapdragon roots exposed to different $\mathrm{Cu}$ and $\mathrm{Si}$ concentrations. ${ }^{\mathrm{z}}$

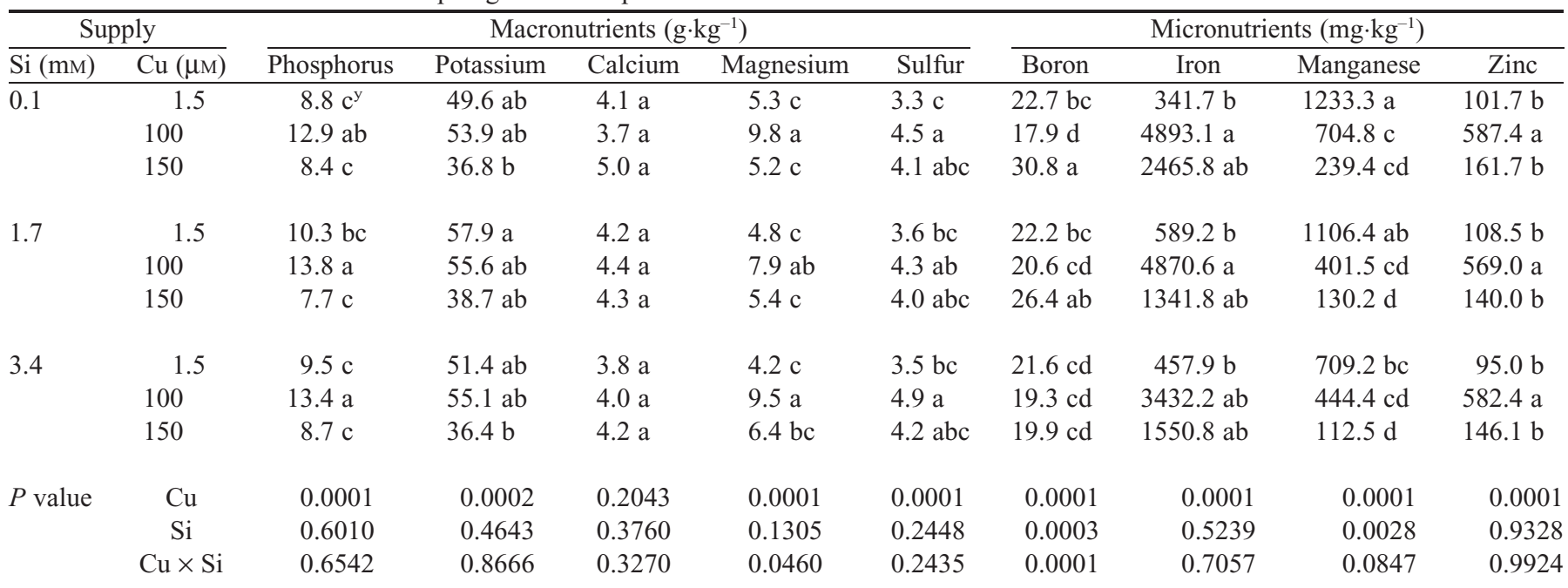

zProbability values are reported for main effects from $\mathrm{Cu}$ and $\mathrm{Si}$ supply as well as the interaction between the two. For all treatment groups, $\mathrm{n}=4$. ${ }^{y}$ Different letters within a column indicates significant differences in means from other treatments for that nutrient based on Tukey's honest significant differences test at $P<0.05$.

$\mathrm{Cu}=$ copper; $\mathrm{Si}=$ silicon. 
Table 6. Nutrient concentrations of snapdragon stems exposed to different $\mathrm{Cu}$ and $\mathrm{Si}$ concentrations. ${ }^{\mathrm{z}}$

\begin{tabular}{|c|c|c|c|c|c|c|c|c|c|c|}
\hline \multicolumn{2}{|c|}{ Supply } & \multicolumn{5}{|c|}{ Macronutrients $\left(\mathrm{g} \cdot \mathrm{kg}^{-1}\right)$} & \multicolumn{4}{|c|}{ Micronutrients $\left(\mathrm{mg} \cdot \mathrm{kg}^{-1}\right)$} \\
\hline $\mathrm{Si}(\mathrm{mm})$ & $\mathrm{Cu}(\mu \mathrm{M})$ & Phosphorus & Potassium & Calcium & Magnesium & Sulfur & Boron & Iron & Manganese & Zinc \\
\hline \multirow[t]{2}{*}{0.1} & 1.5 & $3.9 \mathrm{bc}^{\mathrm{y}}$ & $68.1 \mathrm{ab}$ & $9.5 \mathrm{e}$ & $7.7 \mathrm{~b}$ & $1.2 \mathrm{~b}$ & $19.4 \mathrm{~cd}$ & $23.2 \mathrm{a}$ & $150.4 \mathrm{c}$ & $14.2 \mathrm{~b}$ \\
\hline & 100 & $6.7 \mathrm{a}$ & $56.2 \mathrm{~cd}$ & $13.3 \mathrm{bc}$ & $12.1 \mathrm{a}$ & $2.7 \mathrm{a}$ & $22.8 \mathrm{bc}$ & $11.6 \mathrm{a}$ & $348.5 \mathrm{a}$ & $78.4 \mathrm{a}$ \\
\hline 1.7 & 1.5 & $4.2 \mathrm{~b}$ & $73.0 \mathrm{ab}$ & $12.8 \mathrm{bcd}$ & $7.1 \mathrm{~b}$ & $1.3 \mathrm{~b}$ & $20.7 \mathrm{~cd}$ & $20.1 \mathrm{a}$ & $216.5 \mathrm{bc}$ & $12.5 \mathrm{~b}$ \\
\hline \multirow[t]{3}{*}{3.4} & 1.5 & $4.0 \mathrm{bc}$ & $76.2 \mathrm{a}$ & $10.5 \mathrm{cde}$ & $6.6 \mathrm{~b}$ & $1.2 \mathrm{~b}$ & $18.4 \mathrm{~d}$ & 20.9 a & $265.2 \mathrm{~b}$ & $13.8 \mathrm{~b}$ \\
\hline & 100 & $7.4 \mathrm{a}$ & $64.0 \mathrm{bc}$ & $14.7 \mathrm{ab}$ & $10.3 \mathrm{a}$ & $2.9 \mathrm{a}$ & $25.6 \mathrm{~b}$ & $9.2 \mathrm{a}$ & $365.0 \mathrm{a}$ & $93.3 \mathrm{a}$ \\
\hline & 150 & $3.4 \mathrm{bc}$ & 34.9 e & $9.0 \mathrm{e}$ & $2.1 \mathrm{c}$ & $0.9 \mathrm{bc}$ & $32.5 \mathrm{a}$ & $13.2 \mathrm{a}$ & $69.2 \mathrm{~d}$ & $8.1 \mathrm{~b}$ \\
\hline$P$ value & $\mathrm{Cu}$ & 0.0001 & 0.0001 & 0.0001 & 0.0001 & 0.0001 & 0.0001 & 0.0090 & 0.0001 & 0.0001 \\
\hline
\end{tabular}

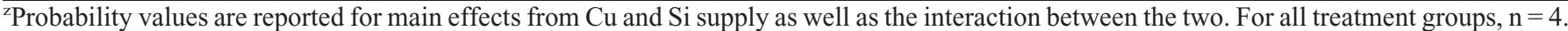
${ }^{y}$ Different letters within a column indicates significant differences in means from other treatments for that nutrient based on Tukey's honest significant differences test at $P<0.05$.

$\mathrm{Cu}=$ copper; $\mathrm{Si}=$ silicon.

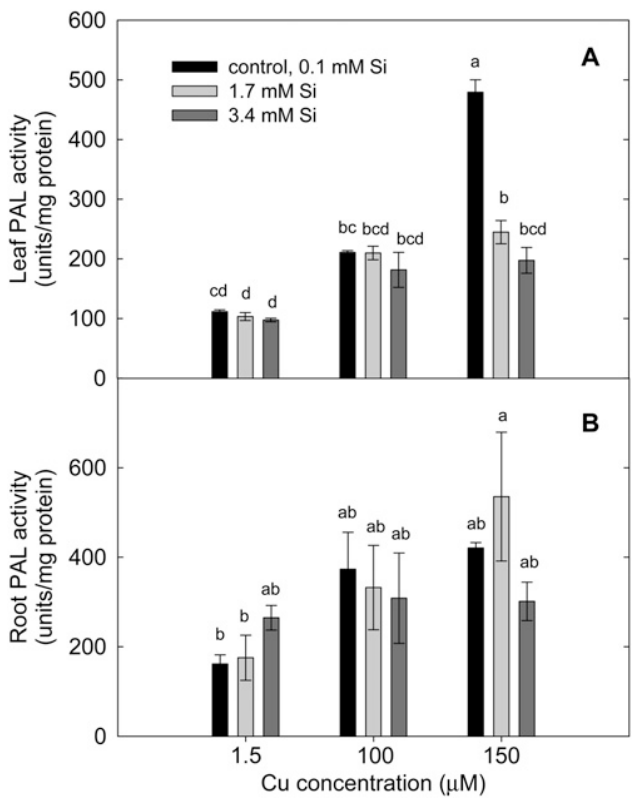

Fig. 7. Average phenylalanine ammonia lyase (PAL) activity of snapdragon shoots $(\mathbf{A})$ and roots $(\mathbf{B})$ with \pm 1 SE. A representative plant was harvested from each hydroponic bucket so values are averages of four plants in each treatment. Treatments consisted of low $(0.1 \mathrm{~mm})$, medium $(1.7 \mathrm{~mm})$, and high (3.4 mM) supplemental silicon and 3 weeks after exposure to control $(1.5 \mu \mathrm{M})$, medium $(100 \mu \mathrm{M})$, and high $(150 \mu \mathrm{M})$ copper. Different lowercase letters above the bars within a panel indicate statistically different means based on Tukey's honest significant difference test at $P<0.05$.

more cell wall binding sites for $\mathrm{Cu}$, thus reducing its apoplastic bypass flow as proposed for other metals (Ma and Yamaji, 2006). Because snapdragon is not as effective at accumulating $\mathrm{Si}$, this element may play strictly a more active role (exclusively modulating stress pathways) for the generation of $\mathrm{Cu}$-binding sites. It has been observed that in cucumber, shortly after removal of supplemental Si (days), plants can no longer effectively combat powdery mildew (Sphaerotheca fuliginea) stress despite tissue concentrations remaining high (Samuels et al., 1991). This strongly indicates that a soluble fraction of $\mathrm{Si}$ is necessary to elicit $\mathrm{Si}$-induced resistance, and because $\mathrm{Si}$ is so poorly soluble, a steady, consistent supply is necessary to derive maximum benefit. It is also possible that snapdragon uses additional mechanisms to alleviate $\mathrm{Cu}$ stress and perhaps only activates $\mathrm{Si}$-mediated processes once a particular threshold is exceeded. Support for this hypothesis comes from the observation that a much higher level of $\mathrm{Cu}$ was needed to elicit a detrimental response in snapdragon as compared with zinnia. It could also be proposed that $\mathrm{Si}$-accumulators already possess the necessary machinery to take advantage of $\mathrm{Si}$, whereas $\mathrm{Si}$ non-accumulators lack some or all of the extensive genetic or enzymatic machinery for such responses.

Noting that $\mathrm{Si}$ is omnipresent in the lithosphere and that our understanding of Si's role in plant biology is still under development, Epstein (1999) wrote that fertilizer recommendations and hydroponic solutions that do not consider Si are at worst an artifact of real-world situations. Because more and more species are found to respond to $\mathrm{Si}$ in different stress situations, we should consider including $\mathrm{Si}$ in fertility programs at least in research situations to account for these yet-to-be-described pathways. It has been observed that detrimental effects can occur with elevated supplemental Si (Kamenidou et al., 2008), but the effect is not widely appreciated. The fact that some subset of species responds with a set of characteristics that we view more favorably than others in our production systems should not cloud the fact that a much broader range of species responds in some measurable way to supplemental Si than previously thought. At best, this response could enhance additional management practices, whereas at worst, Si response may exacerbate them. Not including Si in fertility management practices may inhibit a better understanding of the general plant response to stress.

\section{Literature Cited}

Alonso, M.L., J.L. Benedito, M. Miranda, C. Castillo, J. Hernández, and R.F. Shore. 2000. The effect of pig farming on copper and zinc accumulation in cattle in Galicia (north-western Spain). Vet. J. 160:259-266. 
Bélanger, R.R., P.A. Bowen, D.L. Ehret, and J.G. Menzies. 1995. Soluble silicon: Its role in crop and disease management. Plant Dis. 79:329-336.

Bélanger, R.R., W. Remus-Bore, J. Vivancos, J. Montpetit, C. Gregoire, G. Arsenault-Labrecque, C. Labbe, F. Belzile, and J.G. Menzies. 2010. To absorb or not: The importance of silicon transport in plants, p. 239-256. In: Rodrigue, F.A. (ed.). Silicio na agricultura: Anais do V simposio brasileiro sobre silicio na agricultura. Universidade Federal de Viçosa, Viçosa, Brazil.

Brady, N.C. and R.R. Weil. 2001. The nature and properties of soils. Prentice Hall, Upper Saddle River, NJ.

Bucher, A.S. and M.K. Schenk. 2000. Characterization of phytoavailable copper in compost-peat substrates and determination of a toxicity level. J. Amer. Soc. Hort. Sci. 125:765-770.

Cook, C.M., E. Vardaka, and T. Lanaras. 1997. Concentrations of $\mathrm{Cu}$, growth, and chlorophyll content of field-cultivated wheat growing in naturally enriched Cu soil. Bull. Environ. Contam. Toxicol. 58:248-253.

Datnoff, L.E. and F.A. Rodrigues. 2005. The role of silicon in suppressing rice diseases. 5 May 2011. <http://www.apsnet.org/ publications/apsnetfeatures/Pages/SiliconInRiceDiseases.aspx $>$.

Epstein, E. 1999. Silicon. Annu. Rev. Plant Physiol. Plant Mol. Biol. 50:641-664.

Frantz, J.M., J.C. Locke, L. Datnoff, M. Omer, A. Widrig, D. Sturtz, L. Horst, and C.R. Krause. 2008. Detection, distribution, and quantification of silicon in floricultural crops utilizing three distinct analytical methods. Commun. Soil Sci. Plant Anal. 39:2734-2751.

Frantz, J.M., J.C. Locke, D. Sturtz, and S. Leisner. 2010. Silicon in ornamental crops: Detection, delivery, and function, p. 111-134. In: Rodrigues, F.A. (ed.). Silicio na agricultura: Anais do V simposio brasileiro sobre silicio na agricultura. Universidade Federal de Viçosa, Viçosa, Brazil.

Ghareed, H., Z. Bozso, P.G. Ott, C. Repenning, F. Stahl, and K. Wydra. 2011. Transcriptome of silicon-induced resistance against Ralstonia solanacearum in the silicon non-accumulator tomato implicates priming effect. Physiol. Mol. Plant Pathol. 75:83-89.

Gillman, J.H., D.C. Zlesak, and J.A. Smith. 2003. Applications of potassium silicate decrease black spot infection in Rosa hybrida Meipelta (Fuschia Meidland). HortScience 38:1144-1147.

Hoang, T.C., L.J. Schuler, E.C. Rogevich, P.M. Bachman, G.M. Rand, and R.A. Frakes. 2009. Copper release, speciation, and toxicity following multiple floodings of copper enriched agriculture soils: Implications in Everglades restoration. Water Air Soil Pollut. 199:79-93.

Horst, W.J. and H. Marschner. 1978. Effect of silicon on manganese tolerance of beanplants (Phaseolus vulgaris L.). Plant Soil 50:287-303.

Iwasaki, K., M. Fecht, P. Maier, and W.J. Horst. 2002a. Can leaf apoplastic manganese and $\mathrm{Si}$ concentrations explain Si-enhanced manganese tolerance of Vigna unguiculata (L.) Walp.? Dev. Plant Soil Sci. 92:246-247.

Iwasaki, K., P. Maier, M. Fecht, and W.J. Horst. 2002b. Effects of silicon supply on apoplastic manganese concentrations in leaves and their relation to manganese tolerance in cowpea. [Vigna unguiculata (L.) Walp.]. Plant Soil 238:281-288.

Iwasaki, K., P. Maier, M. Fecht, and W.J. Horst. 2002c. Leaf apoplastic silicon enhances manganese tolerance of cowpea (Vigna unguiculata). J. Plant Physiol. 159:167-173.

Kamenidou, S., T.J. Cavins, and S.M. Marek. 2008. Silicon supplements affect horticultural traits of greenhouse-produced ornamental sunflowers. HortScience 43:236-239.

Korndörfer, G.H. and I. Lepsch. 2001. Effect of silicon on plant growth and crop yield, p. 133-147. In: Datnoff, L.E., G.H. Snyder, and G.H. Korndörfer (eds.). Silicon in agriculture: Studies in plant science. Elsevier Science, Amsterdam, The Netherlands.

Lee, C.W., J. Choi, and C. Pak. 1996. Micronutrient toxicity in seed geranium (Pelargonium $\times$ hortorum Bailey). J. Amer. Soc. Hort. Sci. 121:77-82.
Li, J., S.M. Leisner, and J.M. Frantz. 2008. Alleviation of copper toxicity in Arabidopsis thaliana by silicon addition to hydroponic solutions. J. Amer. Soc. Hort. Sci. 133:670-677.

Liang, Y.C., W.C. Sun, J. Si, and V. Römheld. 2005. Effects of foliarand root-applied $\mathrm{Si}$ on the enhancement of induced resistance to powdery mildew in Cucumis sativus. Plant Pathol. 54:678-685.

Ma, J.F., Y. Miyake, and E. Takahashi. 2001. Silicon as a beneficial element for crop plants, p. 17-39. In: Datnoff, L.E., G.H. Snyder, and G.H. Korndörfer (eds.). Silicon in agriculture: Studies in plant science. Elsevier Science, Amsterdam, The Netherlands.

Ma, J.F. and N. Yamaji. 2006. Silicon uptake and accumulation in higher plants. Trends Plant Sci. 11:392-397.

Ma, J., K. Nishimura, and E. Takahashi. 1989. Effect of silicon on the growth of rice plant at different growth stages. Soil Sci. Plant Nutr. 35:347-356.

Marschner, H. 1995. Mineral nutrition of higher plants. Academic Press, London, UK.

Mattson, N.S. and W.R. Leatherwood. 2010. Potassium silicate drenches increase leaf silicon content and affect morphological traits of several floriculture crops grown in a peat-based substrate. HortScience 45:43-47.

McAvoy, R.J. and B.B. Bible. 1996. Silica sprays reduce the incidence and severity of bract necrosis in poinsettia. HortScience 31:11461149.

Mitani, N. and J.F. Ma. 2005. Uptake system of silicon in different plant species. J. Expt. Bot. 56:1255-1261.

Mocquot, B., J. Vangronsveld, H. Clijsters, and M. Mench. 1996. Copper toxicity in young maize (Zea mays L.) plants: Effects on growth, mineral and chlorophyll contents and enzyme activities. Plant Soil 182:287-300.

Nelson, M.R. 1988. Index to EPA methods. EPA Circ. 901/3-88-01. U.S. Environmental Protection Agency, Washington, DC.

Neumann, D. and U. zur Nieden. 2001. Silicon and heavy metal tolerance of higher plants. Phytochemistry 56:685-692.

Rodrigues, F.Á., D.J. McNally, L.E. Datnoff, J.B. Jones, C. Labbe, N. Benhamou, J.G. Menzies, and R.R. Bélanger. 2004. Silicon enhances the accumulation of diterpenoid phytoalexins in rice: A potential mechanism for blast resistance. Phytopathology 94:177-183.

Rogalla, H. and V. Römheld. 2002. Role of leaf apoplast in siliconmediated manganese tolerance of Cucumis sativus L. Plant Cell Environ. 25:549-555.

Samuels, A.L., A.D.M. Glass, J.G. Menzies, and D.L. Ehret. 1991. Mobility and deposition of silicon in cucumber plants. Plant Cell Environ. 14:485-492.

Stamatakis, A., N. Papadantonakis, and D. Savvas. 2003. Effects of silicon and salinity on fruit yield and quality of tomato grown hydroponically. Acta Hort. 609:141-147.

U.S. Department of Agriculture. 2007. Agricultural chemical usage 2006 nursery and floriculture summary. U.S. Dept. Agr., Natl. Agr. Stat. Serv., Washington, DC.

Uva, W.L., T.C. Weiler, and R.A. Milligan. 2001. Economic analysis of adopting zero runoff subirrigation systems in greenhouse operations in the northeast and north central United States. HortScience 36:167-173.

Zellner, W., J. Frantz, and S. Leisner. 2011. Silicon delays tobacco ringspot virus systemic symptoms in Nicotiana tabacum. J. Plant Physiol. 168:1866-1869.

Zheng, Y., L. Wang, D.F. Cayanan, and M. Dixon. 2010. Greenhouse cucumber growth and yield response to copper application. HortScience 45:1-4.

Zheng, Y., L. Wang, and M. Dixon. 2004. Response to copper toxicity for three ornamental crops in solution culture. HortScience 39:11161120.

Zheng, Y., L. Wang, and M. Dixon. 2005. Greenhouse pepper growth and yield response to copper application. HortScience 40:21322134. 